Article

\title{
On the Philosophical Determination of Literature
}

\author{
Jason Kemp Winfree \\ Department of Philosophy, California State University, Stanislaus, Turlock, CA 95382, USA; \\ jwinfree@csustan.edu
}

Received: 28 November 2017; Accepted: 29 May 2018; Published: 2 June 2018

\begin{abstract}
This paper traces the influence of German Idealism on the conceptions of literature proffered by Bataille and Blanchot, and it aims to show how that influence registers as a proto-ethics. In the demand that freedom be actualized in the world, German Idealism frames the determination of literature as one-sided, subjective, and abstract. Literary expression is never adequate to what it represents. Precisely because it has no direct bearing on the world of action, however, literature is free to pursue that which the world of action excludes: the density and obscurity of existence itself. In this pursuit, literature recasts the philosophical aspiration of self-knowledge in terms of a fidelity to existence and life in excess of individuality.
\end{abstract}

Keywords: Hegel; Bataille; Blanchot; Lispector; writing; death; general life; nondetermination; madness of the day; excess; ethics

The title of this paper is intended to indicate the philosophical aspiration of a certain conception of literature, one that emerges in close proximity to the transmission of Hegel in France between the mid-1930s and the post-war period, and which continues to operate in selected literary works as late as the 1970s. The bellwether of this is Blanchot's 1949 essay, "Literature and the Right to Death," where the author writes: "Let us suppose that literature begins at the moment when literature becomes a question ... The question is addressed to language, behind the person who is writing and the person who is reading, by language which has become literature." (Blanchot 1995) To my mind, two remarkable features stand out here, both of which bear upon defining the inheritance and transformation of Hegel with respect to literature that is at issue in this paper. First, Blanchot treats literature as a question, not an answer. Thus, literature is constituted as a kind of uncertainty or hesitation, an interruption in meaning or intelligibility. Whatever else this entails, surely it is noteworthy that it stands in such sharp contrast to the dominant philosophical conception of literature in France at the time, namely, that proffered by Sartre, for whom literature is a kind of secondary action, the manifestation of a subject's commitment to transform the world. "To speak [or to write] is to act," says Sartre. "Thus, by speaking [or writing], I reveal the situation by my very intention of changing it; I reveal it to myself and to others in order to change it." ${ }^{11}$ Literary language, then, according to Sartre, is subordinate to the primacy of the acting subject, the "instrument of a certain undertaking" that begins in "a decision foreign to the language itself" (WL 15-16). Juxtaposed against this, the second remarkable feature of Blanchot's claim is even more striking than the first: literature is addressed to language and not a reader, by language and not a writer. Here, then, it is not a subject's decision prior to language that accounts for literature, but language in some sense independent of reader and writer alike, language detached from productive action, that brings literature into being. And this should give us pause. For it calls into question the entire metaphysics of subjectivity that

1 (Sartre 1965) "The writer is a speaker; he designates, demonstrates, orders, refuses, interpolates, begs, insults persuades, insinuates," pp. 13-14. 
undergirds Sartre's thought, which understands the human being as producing itself through the transformation of its world. By contrast, for Blanchot literature takes place elsewhere and otherwise, its address situated outside the world, behind the writer and reader, both in the sense of lagging behind them, unable to keep up in the world of action, and in the sense of standing apart from and eclipsed by that world. As we will see, the question that literature poses-and by which it comes into being, constituting itself through this opening-concerns existence, but without respect for particular existents, and worlds of possibility, albeit entire and bereft of developmental capacity. The task of this paper is to trace the genesis and significance of these claims. In this way, I hope to show how the conception of literature here at issue is defined by a transformation of Western philosophy's highest aspirations of self-comprehension, and how this transformation might be understood as a proto-ethical commitment to the sheer fact of existence.

To that end, let us begin by noting four features of Hegel's Phenomenology of Spirit that are crucial for what follows. First, Hegel famously insists in the "Preface" to that work that prefaces as such are ill-suited for philosophy, since they can only summarize what cannot be comprehended by those reading such summaries, if those same readers have not already worked through the text. Philosophy, in other words, is not a set of propositions that could be reported on and submitted to judgment, as if primarily asking us to affirm or deny a set of theses. Instead, philosophy must proceed developmentally, transforming itself as it goes. Philosophy's truth therefore resides entirely in its exposition, according to Hegel, which continuously exhausts itself and starts anew. Philosophical comprehension is not just an end, but is itself a process by which an end is produced, and that process is the only light by which such an end can really be seen. And in this regard, philosophy already appears to share a lot with literature. For every novel or short story, no less than every poem (where the point is perhaps even more obvious), is constituted through a structure whereby the form or exposition, on the one hand, and the content, on the other, are inseparable: one must read the novel in order to "get it." Just imagine construing a work of literature at the level of its propositional truth content! Would that not reduce literature to ideology? In any case, the exposition of Hegel's Phenomenology is not ancillary to the work's truth content, but essential to it. And in this way, Hegel is perhaps the most literary of philosophers.

Second, in order to help clarify the stakes of the Phenomenology, let us note its audacious central task, which Hegel explicitly links to the requirement of philosophy's proper form. He writes: "The true shape in which truth exists can only be the scientific system of such truth. To help bring philosophy closer to the form of Science, to the goal where it can lay aside the title 'love of knowing' and become actual knowing - that is what I have set myself to do." (Hegel 1977). Thus, Hegel is explicitly situating his own work in relation to the history of Western philosophy, where the love of wisdom has from the start been associated with the cultivation of self-knowledge. And he is explicitly announcing that the Phenomenology aims to accomplish something this history has not been able to achieve thus far. We could say that the promise of philosophy as the love of wisdom, the love of knowledge, and ultimately self-knowledge, has according to Hegel remained unfulfilled and must be brought to fruition. What is more, the form of Hegel's exposition - specifically, its scientific form-bears the burden of this, tasked with transforming philosophy's highest aspirations into actual accomplishments. It can do so, according to Hegel, because in contrast to the method of the natural sciences, which remains distinct from its content, philosophical science consists solely and entirely in the elaboration and grasping of the necessary relations by which Spirit develops and comes to know itself. Thus, Spirit comprehends itself through and as its own exposition, which Hegel understands as the consummation of Western philosophy's highest aims.

Third, the Phenomenology begins with an inaugural gesture that establishes the privilege of language over the world of sense-experience and empirical reality. Doing so, Hegel notes that immediate sense certainty is commonly taken to be the most secure and indubitable form of knowledge. According to this supposition, I may be mistaken about inferences connecting one phenomenon with another, but I cannot be mistaken about what I feel right now, say this pinprick, or what I see 
immediately before me, say this tree. Upon closer scrutiny, though, Hegel emphasizes that the object of sense certainty, characterized by the immediacy of the here and now, has always already passed away. Indeed, as soon as I attempt to grasp the here and now, say through writing it down or uttering its truth, an unbridgeable chasm emerges between what is said or named, on the one hand, and what is meant, on the other. Thus, language preserves what is meant (gemeint), what is purportedly immediately mine (meine), but only by transforming it into something else. For what is named is not identical with what is meant, since the name presents what has passed, that is, presents what is not present, and since what is named is no longer just mine but rather belongs to everyone. Hegel writes:

What we say is: 'This', i.e., the universal This ... Of course, we do not envisage the universal This ..., but we utter the universal; in other words, we do not strictly say what in this sense-certainty we mean to say. But language, as we see, is the more truthful; in it, we ourselves directly refute what we mean to say, and since the universal is the true [content] of sense certainty and language expresses this true [content] alone, it is just not possible for us ever to say, or express in words, a sensuous being that we mean. (PS 60)

Simple immediacy, therefore, is ungraspable, unintelligible. The object of sense certainty either is not because it cannot be distinguished and because it passes away, or it is transformed by the preservational work of language. It is only in being negated that immediacy is lifted out of its otherwise formless oblivion. The truth of the 'This', the 'Here', and the 'Now' intended by sense certainty turns out to be the truth of all 'Thises', all 'Heres', all 'Nows'. In this way, Hegel establishes the negativity of language as the real starting point of the Phenomenology, the sin qua non of philosophical comprehension.

Fourth, the Phenomenology's central task is motivated by the need to overcome the Kantian bifurcation of the sensible and the intelligible, the phenomenal and the noumenal, the world of nature and the world of freedom. In Hegel's requirement that freedom actually manifest itself in the world, taking on concrete shape and determination, therefore, the negativity that first appears in the priority accorded to language is extended to the sphere of work. Thus, linguistic determination has an analogue in labor, which negates nature by working on it, thereby lifting nature up into a higher shape, spiritualizing it, transforming it into something else. What really counts here for Hegel, though, is that the products of labor make possible the first vestiges of self-consciousness in the world, and this self-consciousness is specifically determined as the emergence of freedom from bondage. Thus, in Hegel's famous account of the relation of the lord and the bondsman-which in turn is famously interpreted by Kojève in a manner that is decisive for the French reception of Hegel (as we will see below) - the bondsman liberates himself through his work precisely because that work is produced for another. Insofar as this is the case, the bondsman is prohibited from consuming the fruits of his own labor, such that his work possesses for him an independence, an otherness, an objective character. And this satisfies an important external criterion of self-consciousness for Hegel, namely, that every self must have a concrete other with which it can identify if it is to really possess itself as an object. In addition, however, the bondsman only works for the lord because the bondsman himself has undergone the process of determinate negation like the very objects he fashions. Indeed, he is himself constituted as a kind of living negativity, since facing death he has "trembled in every fiber of his being, and everything solid and stable has been shaken to its foundations" (PS 117). Servitude is thus born from a profound fear of death, by which the condition of natural freedom is negated and by which the bondsman qua bondsman becomes what previously as a free person he was not. Because of his misfortune, however, the bondsman also possesses a second requirement of self-consciousness: otherness at the very core of his being. And it is only because this otherness is essential to him that he is able to really identify with his work. Such that in this way, nature, death, and freedom are untethered from natural existence so as to acquire spiritual significance. This process is essential to Hegel's exposition of self-comprehension. 


\section{History, Fragmentation, Art}

Hegel's Phenomenology arrived in France in the late 1930s in large part through the influential lectures of Kojève, which were attended by the likes of both Sartre and Bataille. Emphasizing the development of self-consciousness in the relation of the lord and the bondsman, on the one hand, and Hegel's drive toward absolute knowledge defined by the total commensuration of form and content, process and goal, on the other, Kojève conceived of the end of history in terms of a change in the character of action. ${ }^{2}$ Writing in the shadow of Kojève's influence, Bataille puts it like this: "powerless to change the world, action is changed by it." (Bataille 1988b). This does not mean that humankind will no longer make things, but rather that what is produced no longer contributes to the development of the human, that determinate negation produces without essential transformation. Cast in terms of that section of the Phenomenology that is so decisive to Kojève's analysis, this means the bondsman is no longer capable of recognizing himself in his work, no longer able to bequeath to the future the structure of self-othering by which it could break the cycle of immediate self-certainty. Stripped of its capacity to shape a Sache, homo faber makes art like birds make nets and zoon logon echon realizes itself in "the language of bees." Thus, the end of history is characterized by the total slackening of opposition, where the impotence of action and the overcoming of alienation mark the beginning of contentment, if not happiness. The implicit and the explicit, potentiality and actuality, meaning and truth no longer confront one another, no longer stand in relations of generative opposition. Instead, they are fully and mutually integrated.

In contrast to Kojève, though, Bataille emphasizes that this situation constitutes a loss of virility and a concomitant fragmentation of human being, its reduction to the status of a thing, its fundamental subjection and servility. Just as the shadows of God persist long after his death, according to Nietzsche, so too for Bataille the alienation of human being from itself and the deferral of existence subordinate to future accumulation persist in the very place where one would expect them to disappear. Even where there is nothing left to do, where work is no longer necessary, contentment is thus wretched, even if unbeknownst to those most afflicted by it. ${ }^{3}$ No longer confronting one another, according to Bataille, the elements of generative dialectical opposition therefore fall each to themselves rather than infuse one another in a higher form. The implicit and the explicit, potentiality and actuality, meaning and truth are not integrated, but rather severed so as to no longer bear on one another in even the slightest way. And this condition, according to Bataille, is reflected in the trenchant one-sidedness of the dominant forms of modern life: science, art, and politics. As the productive relations required to maintain life extend their purview beyond the requirements of need, and the temporary suspension of existence in the service of something other than itself gains constancy and primacy, human existence is relegated to the status of a function. ${ }^{4}$ Thus, "[t]he greatest harm that strikes men is perhaps the reduction of their existence to the state of a servile organ," says Bataille. "But no one realizes how desperate and hopeless it is to become a politician, writer, or scientist." ${ }^{5}$

Here, then, we approach the first sense of the philosophical determination of literature, which takes shape in the wake of Hegel's project as inherited through the influence of Kojève's analysis in the conceptualization of modernity by Bataille. We just have seen how that analysis involves the transformation of action by the world, rather than the transformation of the world by action, along

2 Importantly, Sartre neglects just this aspect of Kojève's interpretation-namely, the transformation in the character of action itself-drawing instead exclusively on the formative character of determinate negation with respect to self-consciousness. Thus, Sartre has no conception of what Bataille calls unemployed negativity, and because of that, no sense of literature beyond that of writing as a kind of secondary action intent on transforming the world.

3 "What is missing for the one who is less a man [i.e., who lacks virility] is not satisfaction; nevertheless, his lack is dreaded as a calamity. Hence, this is an ill of the first order, not yet felt by the one stricken: Only the one who must contemplate the threat of future mutilation sees it as harm." Bataille, "Sorcerer's Apprentice," p. 13.

4 As Bataille puts it, "in a world where the need to be a human is missing there is room only for the unattractive face of the useful human being." Ibid., 14, tm.

5 Ibid., $13 \mathrm{tm}$. 
with a condition of fragmentation that both accounts for this and perpetuates it. And we are now in a position to note that according to Bataille the position of science in the modern world exemplifies the dominant face of this situation, and in doing so serves as an important framing factor in the status accorded to literature. According to Bataille, then, science initially arises as a means to an end, but transforms its servile function into an end in itself. Setting aside her own existence, the scientist aims at knowledge of the part, producing truth at the expense of meaning, knowledge detached from the concern for human destiny. ${ }^{6}$ Science acts upon the world and indeed upon us, but like the world of things that it manipulates, we remain essentially the same. We live longer, but not differently. We travel farther and faster without really leaving the comfort of home. Thus, science extends the conditions out of which it is born, reinforcing the detachment of the knower from the known in each of its discoveries and operations, and this is perpetuated in our valuation of its achievements as the privileged form of utility in terms of which hope is cast.

By contrast, art (and this now includes literature for Bataille) aims at meaning, motivated by a concern for the commensuration of human life with the cosmos. In this, it exhibits the structure of self-othering required by Hegel's conception of self-consciousness. The fabrication of material and/or linguistic images negates the immediately real environment, expresses the will of purposive subjectivity as a claim over all objects, asserting the fundamentally human character of the world. But art's and literature's meaning never rises to the level of truth in the sense that it never appears fully in the form of life itself. Art and literature represent freedom, death, the divine, love, but are not themselves ever adequate to these things. Art and literature therefore remain abstract even when representational, essentially one-sided and subjective even in their work of objectification. Because of this, according to Bataille, "The man of fiction suffers from not accomplishing the destiny he describes" even as his will "demands that these fictions be made true." ${ }^{7}$ But that is also to say that to the extent that the images constitutive of art and literature never amount to what they represent, they remain "false with a falsehood that no longer knows either hesitation or shame." ${ }^{8}$ This is decisive. Art and literature are thus meaningful (only) to those who produce them, and (only) on the condition that they not act upon the world so as to become real. Like Hegel's beautiful soul, exemplified in the figure of the romantic poet, the man of literature is satisfied with mere words (Bataille 1988a). He is tolerated by the dominant order only because his requirements are weak and ineffective, because he is resigned to articulate but impotent expression concerning his subjectivity. And this defines the first philosophical determination of literature: measured against the requirement that the idea become real in order to matter, literature is merely subjective satisfaction, falsification, impotent activity. Human being's negativity, by which there can be a world in the first place, makes no meaningful difference in the world. Literature renounces the destiny it represents. ${ }^{9}$

In this way, science and art constitute two sides of modernity's fragmentation, the bifurcation of truth and meaning. Because of its historical formation, however, the function of art is more equivocal than that of science, which vectors servile origins rooted in need. By contrast, art stands in direct proximity to sovereignty, which it is historically tasked with representing. Thus, on the one hand, art

6 "A man who takes upon himself the burden of science has exchanged his concern for living out a human destiny for a concern to discover truth. He moves from the whole to the part, and serving this part requires that the other parts no longer count." Ibid., $15 \mathrm{tm}$.

7 Ibid.

8 Ibid.

9 It is worth noting here that in this context Bataille does not distinguish between different kinds of literature. It is also worth noting that during this same period, Bataille withheld his own novel, The Blue of Noon (completed in 1935), from publication. The "Sorcerer's Apprentice" (1938) tells us why: fiction must renounce the destiny it represents. And when The Blue of Noon finally is published in 1957, Bataille's treatment of literature appears to undergo a shift, one marked by the publication of Literature and Evil during that same year, where Bataille writes: "Literature is either essential or it is nothing ... it demands a 'hypermorality." See Literature and Evil, trans. Alastair Hamilton (London: Marion Boyars, 1997), ix. And yet, to the extent that Literature and Evil distinguishes between types of literature, it is not as a matter of genre, but rather concerns the difference between what Bataille calls essential and inessential literature, the difference between profound communication and the language of utility. 
clearly serves sovereignty. Art is an effect and tool of power, reinforcing the social order. At the same time, though, sovereignty needs this supplement. For sovereignty is nothing if it is not recognized. And this recognition poses an inherent problem precisely because sovereignty stands essentially apart from the order to which and in terms of which it must appear. That is because sovereignty not only marks a power over things, such that they are shaped by and directed towards it as their purpose, but also expresses a freedom from the world of limited objects, a power excessive to the work of determinate negation. Thus, in a world organized by need and accumulation, sovereign extravagance is unintelligible and dangerous. Art can communicate this excessive power only because the artwork itself is an object belonging to the world of objects like any other, that is, a thing shaped by ends outside itself, while at the same time, on the other hand, compared with the tool, the artwork is gratuitous, conspicuously detached from the order of need and accumulation. In this sense, art does not store or restore energies, but spends them. The artwork thus represents the power of the Church or the throne in its content, its images and object status, but it presents or expresses the power of expenditure in its very existence qua artwork. St. Peter's Basilica does not only belong to the world of limited things. It shapes our postures, demands awe. Borrowing from the world of things, sovereignty spends itself in the artwork, while borrowing from the world of sovereignty (and so not just due to its spatio-temporal specificity), the artwork, we could say, acquires its aura.

As the historical conditions definitive of religious and royal sovereign institutions shift, the function of art nevertheless persists. While Bataille glimpsed this already in the 1930s, it was not until the late 1940s that he formulated the matter in such a way as to crystalize the conception of literature we are working towards. Thus, Bataille comes to emphasize that art endures the loss of sovereign structures, and indeed, because of its historical determination by those structures, takes over the place they once defined. More precisely, "[f]ollowing upon religion," says Bataille, "literature is in fact religion's heir." (Bataille 1986). In other words, literature comes to occupy the place vacated in the modern world by religious practice and the consciousness that practice implies. No doubt this has profound consequences for the Hegelian framework that has so far governed our analysis. Recall then that the Phenomenology is structured by the progressive movement of truth through the consecutive and ever higher stages of art, religion, and philosophy, stages in Spirit's ever more adequate self-comprehension. If literature now follows upon religion, therefore, that would mean that literature either takes religion's place, thus preceding and preparing for philosophy, or that it would usurp philosophy's privileged position, somehow absorbing the demands of absolute freedom. In any case, to the extent that literature qualifies as an art, art is now accorded a higher status than the architecture of Hegel's Phenomenology permits, and this can only have significant repercussions for Hegel's privileged coupling of philosophy and consummate self-knowledge. Inheriting the role once played by religion, literature does indeed prepare for philosophy's central task insofar as literature serves a kind of self-understanding. But doing so, it no longer tends toward self-comprehension, but rather dispossession. And this constitutes the second sense of the philosophical determination of literature at issue in this paper: the manner in which literature elides and shadows what is arguably the most ambitious and rigorous expression of self-knowledge in the West, abrogating the shape and transforming the demands of philosophy.

\section{Death Living a Human Life}

In order to see how Hegel's work harbors the roots of this conception of literature beyond the merely architectural considerations treated above, however, let us return to the Phenomenology one more time. For the most decisive and philosophically profound aspect of that work is not its structural outline, against which we have so far measured the status of literature, and which can all too easily be represented in the now discredited teleological movement from sense-certainty to consciousness, self-consciousness, reason, Spirit, and the absolute knowledge of philosophy. It is rather the insistence that the movement of the work itself must be undergone in order to be comprehended, that is, the 
insistence that comprehension must be won, and that in order that this may be so we must pass through the movement of determinate negation.

This is why we can say death is always already operative in the Phenomenology, and indeed account for its explicit role in the formation of self-consciousness. For, first, understanding is constituted through the negation of natural immediacy. Here it is nature that dies. Thus, in the transition from immediate sense-certainty to perception and understanding, human being discovers a power of division and recomposition that shatters natural existence both outside and inside itself. For Hegel conceives of understanding as breaking apart the natural world in order to reconstitute it as a whole. And language assists this process, as we saw at the outset of our study, dividing things from themselves so that they endure their own disappearance. What is more, in and through these same operations human being sets itself apart from the animal substratum of its own existence, both grasping that animal life upon which it is founded and transcending that same life in doing so. Such is the significance of the spiritualization of nature, death, and freedom we noted in our initial treatment of Hegel above. In this way, an entire set of naïve relations is established by which work and language are tethered to one another in the same unitary structure of determinate negation. Homo faber and zoon logon echon work on the world, negate the merely animal basis of their existence. Human being is constituted in and through the determinate negation of nature.

But all this also implies that human being's essential negativity necessarily be directed toward the human itself, that human being be exposed to its own power of destructive transformation. This means not only that the human negates the animal substratum of its immediately natural life, but that this separation itself requires an acute awareness of the human's own death. Within the Phenomenology, of course, the process of spiritualization by which death is transposed from the natural order to that of self-consciousness takes place in the struggle for recognition. In that struggle, the immediate self-certainty that emerges through the power of understanding is challenged by another who confronts it and threatens it with annihilation. And the explicit threat of death constitutes the condition that leads the self to risk its life, thereby abandoning that certainty which defines its naïve existence, thereby raising it to a new level of self-awareness. ${ }^{10}$ The experience of death therefore generates self-consciousness, which takes death as its form. Hegel writes, "In that experience [of death] it has been quite unmanned, has trembled in every fiber of its being, and everything solid and stable has been shaken to its foundation. But this pure universal movement, the absolute melting-away of everything stable, is the simple, essential nature of self-consciousness, absolute negativity." ${ }^{\prime 1}$ In this way, the exposure to death changes life. Indeed, the life so altered has in an important respect died. For it is now what it was not before. And so for Hegel, it is above all others the bondsman who severs his attachment to natural existence and in doing so makes possible the emergence of that self-consciousness upon which the realization of freedom is predicated.

If death is to be spiritualized, however, it is imperative that the bondsman not actually die. Rather, he must survive death, like Blanchot who was placed before a firing squad in 1945. For death endures only when it does not take place. And in order that this be so, the bondsman must retain the capacity for speech. Thus, death survives only in being re-membered, re-collected, its fundamental dismemberment gathered together. And speech, logos, defines this unifying power, the capacity to make present what is absent. The preservation of death therefore requires its very negation, its annihilation, such that death must withdraw from appearance and live only in that withdrawal. Death is thus essentially related to understanding and speech and not simply somehow prior to them. Kojève designates this-in a phrase that is decisive for Bataille and Blanchot alike-“death living a human life."12

10 As Hegel puts it: "The individual who has not risked his life may well be recognized as a person, but he has not attained to the truth of recognition as an independent self-consciousness." Hegel, Phenomenology of Spirit, p. 114.

11 Ibid., p. 117.

12 Cited in (Bataille 1997). 


\section{From Sacrifice to Literature: “The Savage Freedom of Negative Essence"}

This means, at the very least, that death cannot be known immediately, that it must be denaturalized if it is to be grasped. Bataille states the problem clearly: "In order for man to ultimately reveal himself to himself, he would have to die, but he would have to do it while living - watching himself ceasing to be. In other words, [ultimately] death itself would have to become (self-) consciousness at the very moment that it annihilates the conscious being." ${ }^{13}$ This impossible situation therefore requires subterfuge. For this reason, Bataille insists that Hegel was indeed right, but did not in fact know how right he was, unable to fully draw out the consequences of his own insight that death is the truth of human being, that Spirit attains its life only in dismemberment. Thus, according to Bataille, the function of sacrifice reveals on a universal scale what Hegel attempted to express in the limited form of discursive thought. Note, then, that sacrifice presupposes the satisfaction of human being's material needs. It arises only in situations of relative abundance, and it commits this abundance to the excess that it is by destroying its utility, denying the limited status of things. Burnt offerings cannot provide nourishment. Eviscerated slaves cannot work. When the animal is sacrificed, it is the animal in human being that is destroyed, since the conditions required by natural existence are denied in the squandering of resources. When the Aztec priest covers himself in the wet, warm flayed skin of his victim and consumes the still beating heart, he literally inhabits and ingests the other, as though there is no difference between him and his victim. Through the subterfuge of these substitutions, sacrifice effects an intimacy with death. In one fell swoop, sacrifice produces the sacred, spiritualizes human being, and grants access to death. The entire operation is incommensurate with both the immediacy of nature and the profane world of work. And this changes everything: no longer a matter of parsimony and accumulation, but generosity and expenditure.

If literature inherits the role once played by religion, for Bataille that means it is in some sense heir to the function of sacrifice. And this is possible only because literary language shares so much with the structure of sacrifice in the first place. ${ }^{14}$ For sacrifice and literary language both live on death, exposing human being to a world no longer limited by the practical knowability of things and the temporality that implies. Thus, just as sacrifice destroys the utility in human being and things, both negating and intensifying the triumph over immediacy that distinguishes the human from the animal, so too literary language negates the ordinary language of everyday practice and takes up the power of the word itself, which harbors death. Both sacrifice and literary language, therefore, pass through death so as to preserve it. Both live from irrecuperable loss.

Thus, in one respect, the name points to the thing, makes it manifest. There is a table. The flowers are beautiful. But at the same time, as we saw in the context of our earliest remarks concerning Hegel, language negates the thing, transposes it into meaning, significance, value. Words persist where things do not, make present what is not there. But ordinary language ignores this essential negation, suppresses the destruction operative at the heart of speech. What is more, it does so assisted by the familiarity that language itself has helped secure, and it is enabled by the world of things that language miraculously distinguishes as they press in upon us. Ordinary language wants the cat to be a cat and Puss rubs against your leg wanting to be fed. Yet "speech is not sufficient to the truth it contains," Blanchot emphasizes pursuant of the consequences of linguistic negativity, and "literary language is made of uneasiness" over just this insufficiency. ${ }^{15}$ "Take the trouble to listen to a single word," he writes: "in that word, nothingness is struggling and toiling away, it digs tirelessly, doing its utmost to

\footnotetext{
13 Ibid., p. 287.

14 "Man does not live by bread alone," says Bataille. He "takes part in rites and performances. Or else he can read: to the extent that it is sovereign-authentic-literature prolongs in him the haunting magic of performances, tragic or comic." Ibid.

15 The Work of Fire, pp. 325-26.
} 
find a way out, nullifying what encloses it - it is infinite disquiet, formless and nameless vigilance. This is the savage freedom of the negative essence."16

Indeed, language constitutes the world only in always already breaking with it. The power of detachment that makes possible practical endeavor and shapes the Sache in conversation and negotiation cannot be contained by the determination it conditions. ${ }^{17}$ Thus, linguistic being not only consists in a power over things, but a freedom from the world of things, a freedom from the worlds of work, politics, science, the past, the future. Hegel's Phenomenology, Husserl's epoché, Heidegger's step back, Melville's whiteness of the whale, Bataille's dislocated eye, Lispector's cockroach transforming her room into the expanse of Asia Minor-each of these exercises an essential freedom, repudiating the real world of daily concern, contesting its authority. Literature has the decisive advantage over philosophy, though, of exhibiting the reality of this detachment in the fiction of its representations. For in the work of fiction the break with the real announces itself as the sole reality that occupies the writer and reader alike. ${ }^{18}$ Indeed, as we saw with respect to Bataille's early treatment of literature, in images of the imagination all is "false with a falsehood that no longer knows either hesitation or shame." 19 But this means something entirely different from the vantage point of a world still defined by action (even if action itself is altered by a recalcitrant environment) and the vantage point of linguistic negativity, which harbors the power to both grant the world of productive endeavor and take it away. The lack of hesitation and shame characteristic of a literature that is condemned by the real world of action is thus at the same time, but in an entirely different register, itself a condemnation of the real world. For the impotence of action is not only the consequence of a world that does not yield to productive negation, it also belongs essentially to literary language itself, which ruins action from the other side, as it were, always already detached from the conditions required by efficacy.

If literature can be said to act, then, its fundamental accomplishment is its detachment from the world of effort, work, and achievement. And if this produces further consequences in the everyday world of human endeavor, they are indirect, unintended, and accidental. Toni Morrison's Beloved or James Joyce's Ulysses do not tell you what to do or how to do it. That is not only because they do not really belong to the world of things and the means-ends relations that govern that world, but also because they constitute entire worlds unto themselves. Or, as Blanchot puts it:

The realm of the imaginary is not a strange region situated beyond the world, it is the world itself, but the world as entire, manifold, the world as whole. That is why it [literature] is not in the world, because it is the world grasped and realized in its entirety by a global negation of all individual realities contained in it ... because now it is seeing and naming them from the starting point of everything. ${ }^{20}$

Thus, literature is not a thing in the world, nor is it a kind labor upon the world, as Sartre would have it, precisely because literary language breaks from the everyday world, which it could never posses in its entirety. Because of this, however, everything is possible for literature and each work of literature

16 Ibid. Hegel also knew this, of course, and the Phenomenology and the Logic alike do nothing but pursue and struggle with the consequences that follow. For this very reason, Blanchot frames the uneasiness of literary language by emphasizing Hegel's treatment of the original word of Adam, which gave human being dominion over the animals, a sovereignty directly related to the power of death. "In speech what dies is what gives life to speech; speech is the life of that death, it is the 'life that endures death and maintains itself in it."' Blanchot, The Work of Fire, 327. Notably, four years before Blanchot commits these words to writing, Bataille paraphrases what he takes to be Kojève's fundamental insight: for Hegel "it is both fundamental and altogether worthy of astonishment that human understanding (that is, language, discourse) should have the force (an incomparable force) to separate its constitutive elements from totality." That is why man is "death living a human life." Bataille, "Hegel, Death, and Sacrifice," 280.

17 "There is being - that is to say, a logical and expressible truth-and there is a world, because we can destroy things and suspend existence." Blanchot, The Work of Fire, p. 336.

18 "This kind of literature has on its side the fact that it is not trying to deceive us: it presents itself as imaginary; it puts to sleep only those who want to go to sleep." Ibid., p. 317.

19 Bataille, "Sorcerer's Apprentice," p. 15.

20 Blanchot, The Work of Fire, p. 316. 
contains the totality of that possibility. That is, each work of literature contains everything, not in the sense of the serial collection of all objects great and small in the universe, world, or a life, but in the sense of the total concentration of force by which there is a universe, world, or life at all. Thus, "I'm speaking of the vital element that binds things," says Clarice Lispector's G.H., rightfully concerned that because of this she will be dragged away and locked up by those representing the power of organization in the world of determinate action (Lispector 2012). And so literary imagination requires what Maurice Blanchot calls vigilance, watchfulness over the total world literature opens in each case. While there are no rules for this, it is nevertheless noteworthy that literatures of verisimilitude, like philosophies of timely relevance, risk becoming propaganda, be it socially progressive, such as Uncle Tom's Cabin, or viciously reactionary, such as Atlas Shrugged. In either case, the freedom of literary expression fails precisely in the attempt to serve what is taken to be the realization of freedom in the world. Thus, in order that literature's detachment from the sphere of everyday action be effected, in order that it not be reducible to a thing in the world or an operation upon it, in order that anything truly be possible, in order that literary imagination not be stifled, literature must abandon all claims of morality. That is why Blanchot insists: "the greater the pretension to morality and seriousness, the more surely will mystification and deceit triumph." ${ }^{21}$ And Lispector's G.H. echoes this: "I was freeing myself from my morality, and that was a catastrophe without crash and without tragedy." 22

\section{Literary Language and the Obscure Regions of Existence}

Because literature cannot answer to the demands of the world, because it cannot deliver justice, realize freedom, or satisfy knowledge, it is, according to Bataille, guilty (Bataille 1998). ${ }^{23}$ Unjustified, possessing no rights over itself, literary language falters under the scrutiny that would make of it something like fixed testimony with a definitive beginning and end, transmuting the literary event into a determinate thing in the world. Such demands make literature disappear. ${ }^{24}$ In Blanchot's remarkable work, "Madness of the Day," the narrator is confronted by doctors and police-those figures in whom we most obviously encounter the authority of science and politics in our daily lives-and they demand an account of what has happened. They want justice and healing. They want to know who threw glass in the narrator's eyes, when, and why. They want to determine the loss of vision and action the narrator has communicated to us, and indeed communicated in such a way as to both refuse and elicit the demand for further clarification. The authorities, we are told, "remained firmly convinced ... that a writer, a man who speaks and who reasons with distinctions is always capable of recounting facts that he remembers." (Blanchot 1999). The authorities, in other words, demand that language correspond to the facts. And so the narrator responds, repeating the first lines of the récit: "A story? I began: I am not learned; I am not ignorant. I have known joys." 25 In this way, though, "The Madness of the Day" formally ruins its own beginning and end, transposing the work's opening and closure onto one another, such that the story has no proper point of departure and no proper conclusion. Because of this, it both collapses in upon itself and infinitely expands (See Derrida 1992). ${ }^{26}$ But this means precisely that the narrator does not answer as he is asked to do, that literary language has always already begun on the other side of the demand that it recount the facts or produce intelligibility. And so the narrator

21 Blanchot, The Work of Fire, p. 308

22 Lispector, The Passion According to G.H., p. 84.

23 "Before the necessity of action, we are overwhelmed with Kafka's honesty, which attributes no rights to itself." Blanchot echoes this point two years later: "When Kafka chances to write the sentence 'He was looking out the window,' he ... apparently cannot be asked to justify this sentence, since for him nothing else exists." Blanchot, The Work of Fire, p. 305.

24 "If reflection, imposing as it is approaches literature, literature becomes a caustic force, capable of destroying the very capacity in itself and in reflection to be imposing. If reflection withdraws, then literature once again becomes something important, essential, more important than philosophy, the religion or the life of the world which it embraces." Ibid., p. 361. Thus literature, for Blanchot as for Bataille, replaces religion and philosophy.

25 Ibid.

26 Derrida calls this the "double chiasmatic invagination of edges ... [an] ellipsis unremittingly canceling itself within its own expansion." 
repeats the question that initiates the contractive-expansive repetition of the récit. "A story?" But this time he does not begin again, reiterating the first lines of the text. Instead, this: "No. No stories, never again." (see Derrida 2011). ${ }^{27}$ This does not mean that literature can no longer take the form of a story, beginning and concluding as all great stories do, but rather that it can no longer coincide with itself, and in fact, that it never has done so anyway. No more stories means that the beginning of a story can only open onto what the story qua properly delimited narrative cannot contain.

The negativity of literary language is not only the product of historical determination, a form of literary expression specific to modernism, but is rooted in the structure and operation of literature itself. "Spurned by history [i.e., the world of action], literature plays a different game," says Blanchot, and for him this is true of Sophocles no less than Beckett. ${ }^{28}$ That does not mean literature always assumes the same form or social function, but that at its core there is an excess capable of making its distinction from the world into an absolute value. ${ }^{29}$ Doing so, says Blanchot, "this separateness [then] seems to be a source of general understanding, the capacity to grasp everything and attain everything immediately, for those who submit to its enchantment enough to emerge from both their life, which is nothing but limited understanding, and time, which is nothing but a narrow perspective. ${ }^{\prime 30}$ Literature plays this different game, expanding understanding and opening time, by allowing what does not exist discretely to speak. That does not mean only or even primarily that literature invents sentences placed in the mouths of imaginary characters, but that literature presents what hides beneath the world of everyday productivity, exposes what clarification destroys, marks what cannot be demarcated.

"The Madness of the Day" exhibits this operation with remarkable economy and grace, and because of this it merits further attention. Thus, the reader is immediately oriented to a personal life at once so general as to be almost entirely indistinct, and a general life whose personal experiences are so concrete as to be unintelligible. The narrator tells us about himself, but what he says could be true of almost anyone: "I am not learned; I am not ignorant. I have known joys ... I am alive ... I have gone from place to place ... I do not have leprosy, I am not blind, I see the world." ${ }^{31}$ At the same time we have no sense of how or why the singular and concrete events recounted in the récit come to be at all: that the narrator was made to stand against a wall (Blanchot 1998; Derrida 1998) ${ }^{32}$, what kind of illness hospitalized him, that a madman stabbed his hand with a knife, or that another ravaged his eyes with glass. And yet the central event of the story, which arises out the blue and without warning sinks just as quickly into obscurity, the event that the narrator is called upon to account for by the authorities, and which he reports in the simplest factual language- "I nearly lost my sight because someone crushed glass in my eyes" 33 — this event reorients us to what vision does not itself see, but what is in fact presupposed by all determination: light, consciousness, the anonymous persistence of being. In this, as readers, we witness the peculiar power of literary language, according to Blanchot, which transforms the value of transparency into an act of sheer violence: shards of glass in the eyes. We enter a world bereft of things, vision without determinate objects, light that does not reveal but "sympathizes with darkness." 34 The narrator tells us how with eyes bandaged he had to hold his own "against the light of seven days," seven days all at once, seven days of undifferentiated light, light

27 "Madness of the Day" first appeared under the title "Un récit?" Published in 1973 under the title "Madness of the Day," the word récit no longer appears on the cover or title page.

28 Blanchot, The Work of Fire, p. 339.

29 Thus, it is not a matter here of treating the question of literature with respect to a certain genre, or treating this question itself as belonging to a certain genre. It is rather a matter of the structure, movement, or operation upon which any genre as such would depend. That is, it is a matter of the extent to which literature as such does not and cannot belong to a genre. In his essay addressing Blanchot's "Madness of the Day," Derrida calls this "the law of genre ... the law of overflowing, of excess, the law of participation without membership ...." Acts of Literature, pp. 228-29.

30 Work of Fire, p. 317.

31 Blanchot, "Madness of the Day," p. 191.

32 An explanation of sorts, The Instant of My Death was published twenty-one years after "Madness of the Day" appeared under that title, and forty-five years after its still earlier appearance under a different title. See above note 35.

33 Blanchot, "Madness of the Day," p. 194.

34 Blanchot, The Work of Fire, p. 330. 
before the creation of the world, light untethered from the world of determinate objects, and he tells us how that condition ruined him. "The worst thing was the sudden, shocking cruelty of the day," he says. "I could not look, but I could not help looking. To see was terrifying, and to stop seeing tore me apart from my forehead to my throat. ${ }^{35}$ It is as though the narrator is sacrificed by the light of day, present to his own death in the contact he makes with existence bereft of existents.

At times I said to myself: "This is death." ... But often I lay dying without saying anything. In the end, I grew convinced that I was face to face with the madness of the day. That was the truth: the light was going mad, the brightness had lost all reason; it assailed me irrationally, without control, without purpose. That discovery bit straight through my life. ${ }^{36}$

Then, as he recovers, as the bandages are removed and he returns to the world of work and things where he is asked to give an account of what happened, he tells us that he has "not forgotten the agonizing contact with the day" and that he has "the same desire for the daylight as for water and air." 37 That is why he refuses to provide an account, to tell a(nother) story.

Only this refusal grants access to the obscure regions of existence where wakefulness encounters the incessance of its own light alongside the density of the world. The consciousness of death was supposed to produce self-possession, as we saw in Hegel. But literary language dispossesses the self, empties it of personhood. Its entire movement is given in the slippage from the first person singular (I) to the third person singular (he/it), the emergence of the neuter that is inscribed in the detachment effected by literary language from the start (Lacoue-Labarthe 2015). ${ }^{38}$ Here, in a certain respect, one dies. But we should not overstate the case. Words do not really kill anybody. They do, however, transport the subject beyond the action, knowledge, and history that constitute its identity. They harbor the capacity not just to account for our lives, but to turn us toward what exists anonymously in ourselves and the world, and so they harbor the capacity to ruin us. Clarice Lispector is getting at something like this when she writes: "The great neutral punishment of general life is that it can suddenly undermine a single life; if it isn't given its own power, then it bursts as a dam bursts—and arrives pure, unadulterated: purely neutral." ${ }^{\prime 39}$ Literature bursts the dams that organize everyday existence and works to safeguard the general life that belongs to no one in particular. Beneath my death literature discovers anonymous existence, undifferentiated life. "[W]hat I was seeing was life looking back at me," says G.H., "centuries and centuries inside a mud ... I'd looked at the living roach and was discovering inside it the identity of my deepest life." 40 Thus the writer has only one subject, according to Blanchot: "The horror of existence deprived of the world, the process through which whatever ceases to be continues to be, whatever is forgotten is always answerable to memory, whatever dies encounters only the impossibility of dying ... existence without being." ${ }^{\prime 11}$

35 Blanchot, "Madness of the Day," p. 194

36 Ibid., p. 195

37 Ibid.

38 Compare, especially in the context of the legacy of German Idealism: "Purifying myself once meant a cruelty against what I called beauty, and against what I called ' $\mathrm{I}$ ', without knowing that ' $\mathrm{I}$ ' was an accretion of myself. But now my most difficult fright-I am finally heading toward the inverse path. I head toward the destruction of what I built, I head for depersonalization." Lispector, The Passion According to G.H., p. 183.

39 Ibid., p. 66.

40 Ibid., pp. 51-52.

41 Blanchot, The Work of Fire, p. 48. And: "Literature does not act: but what it does is plunge into this depth of existence which is neither being nor nothingness and where the hope of doing anything is completely annihilated. It is not explanation, and it is not pure comprehension, because the inexplicable emerges in it." Ibid., p. 340. This is intelligible only when measured against the power of determinate negation in Hegel. Such that Blanchot is insisting that language persists beyond the work of determinate negation as a hum of existence, that there is a form of negativity that no longer works on the world and shapes human being, but occupies a space vacated by individuation. 


\section{Measuring up to the Universe}

Hegel requires the determination of being, the realization of the idea in the world, which is at the same time the consummation of self-comprehension through the process of self-othering. Kojève calls this death living a human life. But literature inverts this movement and expands its structure. No longer the passage from the implicit to the explicit, obscurity to clarity, oblivion to comprehension, but the opening of the explicit, clarified, comprehended onto the implicit, obscure, and incomprehensible. Determinate negation must no doubt first produce a world in order for this to occur, but the world it produces cannot contain the movement that makes it possible. Human being cannot contain life itself. The process of self-othering therefore exceeds the work of determinate negation. Existence exceeds existents. Life surpasses death. Not only does death live a human life, where it is taken up within that life and spiritualized, but life lives in spite of human death, persists beyond individuation. Hegel thus thought that death was the most terrible of all things. But death is a luxury, as Bataille reminds us, something that accompanies only the most extravagant and delicate forms of life (Bataille 1989). Death is reserved for individuals. But individuals live on anonymous existence. Life spends itself extravagantly on those who will die and know this to be the case. And there is a freedom in this. "The roach and I are hellishly free because our living matter is greater than we are, we are hellishly free because my own life is so barely containable inside my body that I cannot use it," says Lispector. ${ }^{42}$ Human being is not only the being who makes meaning in the world, but the one who passes through that meaning to the obscurity of its own existence, which is no longer its own. The human is not just the one who knows that it will die, but the one who knows that its death is a luxury of life itself. "I know it seems I am taking away your and my humanity. But it's the opposite: what I am wanting is to live from the initial and primordial thing that was exactly what made certain things reach the point of aspiring to be human. I am wanting for me to live from the most difficult human part: for me to live from the seed of neutral love." 43

We have seen above that if literature can be said to act, its fundamental accomplishment consists in a separation from the world of work. Thus, literature produces without acting on the world. Its absolute freedom to create the universe anew comes at the price of practical impotence. A hellish freedom that is neither naturalized nor spiritualized, it does not result in or stem from self-possession, but dispossession. Literature does not deliver one through death to more substantial shapes of universal individuality, but opens onto the generality of existence that is life itself. Thus, literature shifts the plane on which the problem of existence is posed.

If there is anything we can learn from this that might be carried over into the world of action, it has to do with the fact that our lives do not fully belong to us, that in our individual existences life spends itself without reserve. For over two thousand years Western humanity has answered the question of how it should live by appealing to a God who creates something out of nothing, the original act of determinate negation. What follows are laws ensuring the respect of individuals and their property, and of course, privileged persons and communities. Georges Bataille asks another question altogether: "How can we live up to the universe if we content ourselves with the slumber of traditional knowledge?"44 The sun does not recuperate its energy but gives gratuitously. Literature presents this excess but does not own it, and it teaches us that we do not own our own lives. Only those who recognize that life exceeds their individual interests, and that their own existence is itself an excess of life, could in any way begin to measure up to the universe. That would require that we learn to spend in a manner that befits our essential luxury, siding with the surplus of undifferentiated life rather than the greed of individual accumulation. Because of this, there is in the work of literature what I would call a hypomorality, that is, a fidelity to existence without respect for individual partition,

42 Lispector, The Passion According to G.H., p. 127.

43 Ibid., p. 169

44 Bataille, The Accursed Share, vol. 1, p. 11. 
a fidelity to the generality of life, a morality below or beneath the moral order of action, like the general life beneath death. ${ }^{45}$ Lispector: "He who lives totally [in identification with the cockroach, for example] is living for others, he who lives his own largeness [which dispossesses him from himself] is making an offering, even if his life takes place within the incommunicability of a cell. Living is such a great offering that thousands of people benefit from every life lived." ${ }^{\prime 6}$ Literature reveals this as sacrifice perhaps also once did.

Augusto Pinochet amassed a library of 30,000 volumes worth $\$ 3$ million while carrying out his campaign of terror in Chile between 1973 and 1990. Among the collection there were virtually no works of literature or poetry. ${ }^{47}$ Rather than books by Chilean Nobel Prize winner Pablo Neruda, or National Prize for Literature winner Jose Donoso, Pinochet prized works on Napoleon and colonial manuscripts documenting Chile's history of conquest. A library of deluded how-to manuals devoted to individual accumulation. Pinochet came to power in a US backed coup orchestrated by Henry Kissinger, who thirty-two years later met regularly with President George W. Bush on Iraq, advising him that "Victory over the insurgency is the only meaningful exit strategy." (Kissinger 2005; Woodward 2007) ${ }^{48}$ This is the legacy of greed, of individual existence fleeing from the generality of its own life, destroying the lives of others. When scarcity threatens, human being must work to ensure its survival. There is no time for the luxuries of death or literature. Book burnings by illiterate Taliban evidence human existence that has not risen above fear, hunger, and ignorance. But the same cannot be said for napalm bombs, dictatorial libraries with no literature or poetry, or preemptive attacks designed to steal another nation's natural wealth. This is what life looks like when having accumulated enough wealth and knowledge to free the entire world from need, the drive for accumulation persists as a sick nostalgia for days of scarcity. This is what the world looks like bereft of that detachment effected by literary language, which presupposes the satisfaction of need and spends itself on the excess of life. This is how we excise ourselves from existence, deaf to the murmur of what is. Of course, literature cannot save us from greed. It is not a political solution. It does not act upon the world. But it is doubtful that we can live fully without a sense of what literature maintains: vigilance with respect to "the savage freedom of negative essence," the obscurity and persistence of existence.

Acknowledgments: In this section you can acknowledge any support given which is not covered by the author contribution or funding sections. This may include administrative and technical support, or donations in kind (e.g., materials used for experiments).

Conflicts of Interest: The author declares no conflict of interest.

\section{References}

Bataille, Georges. 1986. Erotism: Death and Sensuality. Translated by Mary Dalwood. San Francisco: City Lights Publishing, p. 87.

Bataille, Georges. 1988a. Letter to X, Lecturer on Hegel. In The College of Sociology, 1937-39. Edited by Denis Holier. Translated by Betsy Wing. Minneapolis: University of Minnesota Press, p. 91.

Bataille, Georges. 1988b. The Sorcerer's Apprentice. In The College of Sociology, 1937-39. Edited by Denis Holier. Translated by Betsy Wing. Minneapolis: University of Minnesota Press, p. 17.

Bataille, Georges. 1989. The Accursed Share. Translated by Robert Hurley. New York: Zone Books, vol. 1, p. 33.

45 Speaking of literary language, Blanchot writes: "There is ambiguity everywhere: in its trivial exterior-but what is most frivolous may be the mask of the seriousness; in its disinterestedness-but behind this disinterestedness lurks the forces of the world, and it connives with them without knowing them, or again, ambiguity uses this disinterestedness to safeguard the absolute nature of the values without which action would stop or become mortal; its unreality is therefore both a principle of action and the incapacity to act... "Blanchot, The Work of Fire, p. 342.

46 Lispector, The Passion According to G.H., pp. 177-78.

47 http://www.nytimes.com/2014/01/10/world/americas/a-chilean-dictators-secret-book-collection-heavy-on-napoleonlight-on-fiction.html? module=ArrowsNav\&contentCollection=Americas\&action=keypress\&region=FixedLeft\&pgtype $=$ article.

48 http://nsarchive.gwu.edu/NSAEBB/NSAEBB437/; https://www.thenation.com/article/kissinger-and-pinochet/. 
Bataille, Georges. 1997. Hegel, Death, Sacrifice. In The Bataille Reader. Edited by Fred Botting and Scott Wilson. Translated by Jonathan Strauss. Oxford: Blackwell Publishing, p. 280.

Bataille, Georges. 1998. Literature and Evil. Translated by Alastair Hamilton. London: Marion Boyars Publishers.

Blanchot, Maurice. 1995. Literature and the Right to Death. In The Work of Fire. Translated by Charlotte Mandell. Stanford: Stanford University Press, p. 300.

Blanchot, Maurice. 1998. The Instant of My Death. Stanford: Stanford University Press.

Blanchot, Maurice. 1999. The Madness of the Day. In The Station Hill Blanchot Reader: Fiction and Literary Essays. Translated by Lydia Davis, Paul Auster, and Robert Lamberton. Barrytown: Station Hill Press/Barrytown Ltd., p. 199.

Derrida, Jacques. 1992. The Law of Genre. In Acts of Literature. Edited by Derek Attridge. Translated by Avital Ronell. New York: Routledge, pp. 238-39.

Derrida, Jacques. 1998. Demeure: Fiction and Testimony. Translated by Elizabeth Rottenberg. Stanford: Stanford University Press.

Derrida, Jacques. 2011. Parages. Edited by John P. Leavey. Translated by Tom Conley, James Hulbert, John P. Leavey, and Avital Ronell. Stanford: Stanford University Press, pp. 230, 238.

Hegel, Georg Wilhelm Friedrich. 1977. Phenomenology of Spirit. Translated by A.V. Miller. Oxford: Oxford University Press, p. 3.

Kissinger, Henry A. 2005. Lessons for an Exit Strategy. The Washington Post 12: A19.

Lacoue-Labarthe, Philippe. 2015. Ending and Unending Agony: On Maurice Blanchot. Translated by Hannes Opelz. New York: Fordham University Press, p. 36.

Lispector, Clarice. 2012. The Passion According to G.H. Translated by Idra Novey. New York: New Directions Books, pp. 58, 101.

Sartre, Jean-Paul. 1965. What Is Literature? Translated by Bernard Frechtman. New York: Harper Colophon Books, p. 16.

Woodward, Bob. 2007. State of Denial: Bush at War, Part III. New York: Simon and Schuster.

(C) 2018 by the author. Licensee MDPI, Basel, Switzerland. This article is an open access article distributed under the terms and conditions of the Creative Commons Attribution (CC BY) license (http:/ / creativecommons.org/licenses/by/4.0/). 